DOI 10.15826/qr.2021.4.641

УДК 159.923-053.2+94(470)"1954/1964"+271.2

\author{
Страх и детская виктимность \\ в атеистическом дискурсе хрущевского периода
}

Галина Егорова

Национальный исследовательский университет

«Высшая школа экономики»,

Москва, Россия

\title{
Fear and Childhood Victimisation in Atheistic Discourse during the Khrushchev Era ${ }^{\star *}$
}

\author{
Galina Egorova \\ HSE University, \\ Moscow, Russia
}

This article aims to demonstrate the interpretative potential of anti-religious propaganda during the Thaw period through the lens of emotional narrative. The author suggests considering the use of the victimised image of religious children as means for evoking the public's censure during Khrushchev's antireligious campaign. This atheistic campaign was carried out mostly by means of discrediting believers, contrasting them with social norms and the image of the ideal Soviet citizen, a builder of communism. Images of child-martyrs are archetypical in Russian culture; they were often used in stories about Young Pioneer heroes, as well as in visual propaganda during the Great Patriotic War. According to the Soviet media, religious upbringings were based on intimidation; as a result, a sense of fear affected the child's personality. The key components of the image of religious children have been reconstructed through the prism of narratives and pictures in the press, films, letters to the media, ideological books, and handbooks. Sociological surveys of Soviet children and letters of the Soviet people demonstrate that the stereotypes of fearful religious children were quite effective. Studying taboo emotions makes it possible to understand the "emotional

* Исследование осуществлено в рамках Программы фундаментальных исследований НИУ ВШЭ. Автор выражает благодарность Е. М. Болтуновой, рецензентам и редакторам журнала Quaestio Rossica за ценные идеи и вклад в создание этой статьи.

** Citation: Egorova, G. (2021). Fear and Childhood Victimisation in Atheistic Discourse during the Khrushchev Era. In Quaestio Rossica. Vol. 9, № 4. P. 1317-1331. DOI 10.15826/qr.2021.4.641.

Цитирование: Egorova G. Fear and Childhood Victimisation in Atheistic Discourse during the Khrushchev Era // Quaestio Rossica. Vol. 9. 2021. № 4. P. 1317-1331. DOI 10.15826/qr.2021.4.641 / Егорова Г. Страх и детская виктимность в атеистическом дискурсе хрущевского периода // Quaestio Rossica. Т. 9. 2021. № 4. С. 1317-1331. DOI 10.15826/qr.2021.4.641.

(C) Егорова Г., 2021

Quaestio Rossica • Vol. 9 • 2021 • № 4, p. 1317-1331 
scope" of Soviet propaganda in a more profound way, as well as to identify the formation of the "emotional component" of the "the Other". Geographically, the research covers central Russia - the region which was given much attention by the media due to a historical legacy that appealed to the concept of Holy Rus?.

Keywords: N. S. Khrushchev's anti-religious campaign, victimhood, fear, Central Russia, Soviet childhood

Цель исследования состоит в том, чтобы показать возможности интерпретации антирелигиозной пропаганды периода оттепели как эмоционального нарратива. Автор предлагает взглянуть на использование виктимизированного образа верующих детей для формирования осуждающей общественной реакции в период антирелигиозной кампании Н. С. Хрущева. Борьба с религиозностью населения преимущественно сводилась к стратегии дискредитации верующих, противопоставлению их социальным нормам и образу идеального советского человека - строителя коммунизма. Образы детей-мучеников являются архетипичными для русской культуры, к ним неоднократно обращались в XX в. в сюжетах о пионерах-героях, а также в средствах визуальной пропаганды периода Великой Отечественной войны. Ключевой составляющей образа верующих детей по версии атеистической пропаганды стало чувство страха, которое возникало в результате особенностей религиозного воспитания, основанного на устрашении и запугивании. В статье на основе широкого круга источников - от идеологизированных пособий о вреде религии для детей до материалов визуальной пропаганды - анализируются основные составляющие образа верующих детей и молодежи. Изучение материалов социологических опросов, писем в прессу и общественных акций, направленных на «спасение» детей из религиозных семей, показывает высокую степень эффективности сформированных в рамках этой кампании стереотипов. Приписывание верующим табуированных эмоций позволит глубже изучить «эмоциональный диапазон» советской пропаганды, а также отследить механизм формирования эмоциональной составляющей образа Другого. Территориальные границы исследования представлены Центральной Россией - регионом, которому оказывалось повышенное внимание в СМИ в силу значительной сохранности архитектурных памятников, связанных в массовом сознании с традиционной русской религиозностью.

Ключевые слова: антирелигиозная кампания Н. С. Хрущева, виктимность, страх, Центральная Россия, советское детство

8 июля 1962 г. прихожане Успенского кафедрального собора Владимира отправились на воскресное богослужение. Однако попасть в храм им не удалось: у центрального входа их встретила группа из восьми человек, которые заявили, что по распоряжению Владимирского городского комитета коммунистической партии на время богослужения дети не могут присутствовать в храме с родителями, а будут находиться в детской комнате Дворца пионеров, расположенного 
рядом на площади Свободы, где им уже приготовили игрушки, книжки с картинками и т. д. Попытки отобрать детей у верующих вызвали решительный отпор с их стороны: «перед собором собралась толпа с большим задором и гневом кричавших и нападающих на других лиц». Для разрешения конфликта архиепископ Владимирский Онисим (Фестинатов) через председателя приходского исполнительного органа Паршенкова попросил активистов предоставить документы, подтверждающие законность их действий. В связи с отсутствием соответствующего документа «инициативной группе» предложили удалиться с территории собора [История религий, с. 109].

Действия местных активистов могли быть вызваны публикациями в центральных СМИ о распространении религиозности во Владимирском крае. Считалось, что действующий Успенский собор и многочисленные экспонаты сакрального характера, составившие основу экспозиции Владимиро-Суздальского музея-заповедника, склоняют советских граждан к размышлениям о религии [Шатров; Сувениры суеверий].

За полгода до описываемых событий специальный корреспондент журнала «Крокодил» посетил всенощную в Успенском соборе. Его удивил контингент прихожан, среди которых, кроме «стариков и старух», были мужчины средних лет, занимавшие, судя по разговору, административные должности, а также молодежь и «дети-подростки, главным образом девочки», хорошо знавшие ход богослужения. Осуждение автора вызвали массовое крещение детей по воскресеньям и плохо организованное атеистическое воспитание в городе: «Во Владимире сотни людей только за то и получают заработную плату, чтобы воспитывать нового человека, свободного от предрассудков. Но какой-то лукавый бес все время путает этих людей, сбивает их с пути истинного на путь формального отношения к делу» [Костюков, 1962].

В 1963 г. в «Крокодиле» вышла еще одна статья об организации пасхального богослужения в Успенском соборе г. Владимира. Спецкор «Крокодила» вместе с сотрудниками местной газеты «Призыв» побывал в соборе и наблюдал за происходящим вне его стен. По подсчетам M. Семенова, в Страстную субботу в три часа дня за десять минут пожилые женщины провели в храм 28 детей. Описывая атмосферу в храме, автор прибегает к известному приему - отталкивающим деталям «антисанитарии», где старческая немощь и болезненность противопоставляются невинности и чистоте детства [Панченко]: в очереди к плащанице «надсадно кашляют старухи, хнычут дети», трехлетняя девочка «послушно прикладывается к тому месту, где оставили нечистый след десятки недужных старух и полупьяных прихожан». Пытаясь усовестить бабушку, взявшую в храм внучку семи лет, автор услышал в ответ: «сейчас-то ее только и водить, а то пойдет в школу - силком в церковь не затащишь». Вместе с тем автор с удивлением констатирует, что некоторые дети самостоятельно приходили освящать куличи. Попытки высмеять посещение храма («Ты что же, братец, в святоши записался?») и дальнейшие расспросы наталкиваются на уверенные 
лаконичные ответы школьника. Это поведение, лишенное привычных для образа верующих страха и робости, маркируется отрицательно и противопоставляется борьбе с мракобесием юного Ломоносова, активности юного Гагарина и «душевной стойкости» Павлика Морозова - сакральных личностей для молодого поколения СССР [Семенов].

Кроме Владимира, в начале 1960-х гг. спецкоры «Крокодила» посетили храмы Рязанской и Костромской областей, где также обратили внимание на то, как молодежь вовлекается в церковную жизнь [Никольский; Костюков, 1964]. Эти регионы Центральной России («областные, городские и районные отделы народного образования Ярославля, Владимира, Иваново, Смоленска, Рязани») неоднократно вызывали критику из-за плохо организованной атеистической пропаганды среди молодежи [Школа не может быть нейтральной, с. 13].

Борьба с религиозностью молодежи оформилась в одно из приоритетных направлений антирелигиозной кампании в 1958 г. после официальных рекомендаций обратить внимание на то, что «церковники и сектанты» «проявляют изобретательность в применении новых, более действенных форм привлечения населения, и особенно молодежи и детей, в церковь, религиозные общины и секты», а также что «за последние годы отмечается определенный рост числа граждан, и особенно молодежи, отправляющих религиозные обряды, посещающих церкви, молитвенные дома, мечети, "святые места"» [О недостатках научно-атеистической пропаганды; Смолкин, с. 157].

Воспитание детей в СССР признавалось задачей государственной важности: «От того, как воспитываются, какими вырастут наши дети, во многом зависит будущее нашей страны, дальнейшие успехи строительства коммунистического общества» [Радина, 1955, с. 3]. Призыв оградить подрастающее поколение от «тлетворного влияния религии» был частью государственной программы, а отдельные активисты на местах пытались претворить ее, порой нарушая конституционные права верующих. Например, в 1964 г. в селе Ликино Владимирской области председатель сельсовета запретил совершать таинство крещения над младенцами [История религий, с. 110].

Для партийных идеологов было очевидно, что в атеистическом обществе основным источником формирования религиозных убеждений детей были семья и ближайшее окружение [Беляев; Радина, 1955; Радина, 1961]. Бороться с религиозностью подрастающего поколения решили через дискредитацию образа верующих. В государстве воинствующего атеизма вера выступала отголоском старого, отжившего мира покорных, зависимых людей. Атеистическая пропаганда строилась на противопоставлении идеального советского человека - строителя коммунизма, победителя фашизма, покорителя космоса - советским верующим. Образ верующего, слепленный из удобных для режима стереотипов, включал в себя несколько ипостасей: корыстный служитель культа, манипулирующий доверчивостью прихожан, пожилая женщина, выступающая агрессором по отношению к окру- 
жающим, несчастная молодая женщина/девушка, родители - религиозные фанатики, дети - жертвы их произвола [Федоров]. Вызвать наибольший отклик для борьбы с религиозностью в стране смог именно последний образ.

Ключевой особенностью образа верующего человека стала виктимность: «морально неустойчивый» и «психологически слабый» человек обращался к религии в силу обстоятельств - воспитания в семье, постигшего его горя, одиночества [Притчина; Dobson]. C 1920-х гг. советская педагогическая система была рассчитана на воспитание экстравертов, точнее, «экстравертированного интеллектуального типа», по К. Г. Юнгу: «Глубоко усвоивший и всем сердцем принявший идеи марксизма-ленинизма, этот человек подчиняет служению им и свою собственную жизнь, и жизнь всех, кто рядом с ним и на кого он может повлиять, требует преданности этой идее от себя и от других. Он... не испытывает колебаний, не знает смены настроений, переживает только те эмоции, которые связаны с его служением обществу и этим обществом предусмотрены. Радуется тому, чему предписано радоваться, и огорчается тоже по предписанным поводам. <...> Он не знает собственного спонтанного субъективного процесса, а если и обнаруживает таковой, то получает заслуженное порицание товарищей как слабак и нытик, допустивший непростительную слабость» [цит. по: Орел, с. 103]. В этой парадигме неспособность справиться с личными проблемами, поглощение горем маркировались как недостойное советского гражданина поведение. В список «официально одобряемых» чувств (радость, восторг, праведный гнев, осуждение, стойкость и пр. [Fitzpatrick, p. 357]) эмпатия не входила, поэтому виктимизированный образ верующих вызывал жалость и осудительное снисхождение.

Ключевой особенностью образа верующих стало чувство страха, которое определяло их поведение и образ жизни: «Страх - это неотъемлемое чувство религиозного человека во все времена и у всех народов, начиная от первобытной религии и кончая современным христианством. Возникнув исторически как продукт бессилия человека перед господствующими над ним стихийными силами природы, религия по-прежнему опирается на такие чувства, как страх, горе, направляет его на ожидание лучшей жизни в другом, потустороннем мире. Любое религиозное учение призвано создавать атмосферу боязни, тревоги, преклонения перед “потусторонними силами”, держать верующих в постоянном страхе» [Быкова, с. 37-38].

Частота употребления термина «страх Божий» в священных текстах позволила атеистической пропаганде сделать эту эмоцию доминантной, при этом он лишался своего изначального богословского смысла и понимался буквально. Богобоязненность в христианской традиции - одна из главных добродетелей, которая понималась прежде всего как благоговейное отношение к Богу, «"ужас" оказаться недостойным Бога», осознание собственной нечистоты [Софроний 
(Сахаров), с. 20]. Страх Божий понимался как способ само- и богопознания, как способ достижения любви ${ }^{1}$. Христианская традиция проводила четкую границу между добродетелью богобоязненности («Начало премудрости - страх Господень», Пс. 110 : 10) и «животным страхом» как признаком человеческого несовершенства: «В любви нет страха, но совершенная любовь изгоняет страх, потому что в страхе есть мучение. Боящийся несовершенен в любви» $(1$ Ин : 4, 18). Преподобный Иоанн Лествичник считал «малодушную боязливость» порождением тщеславия и гордости [Иоанн Лествичник].

Использование концепта религиозного страха не только объясняло «странности» в поведении верующих, их «упорство» в соблюдении обрядов и традиций, но и создавало отталкивающий образ жертвы, который стал эффективным средством советской пропаганды. Верующие представали жертвами обмана и махинаций со стороны клира или более предприимчивых братьев по вере. При этом виктимизированный образ верующих в любой момент мог претерпеть инверсию: «жертва страха» становилась агрессором по отношению к зависимым от него, которые не могли постоять за себя, в первую очередь к детям. Этот сюжет часто встречался в средствах визуальной пропаганды еще довоенного времени: известный плакат «Религия - яд, береги ребят» художника Терпсихорова 1930 г. отсылает к образному ряду традиционных русских сказок о Бабе-яге и ребенке, случайно ставшем ее пленником (ил. 5 на цв. вклейке).

С утверждением советской власти ребенку отводилась роль «человека будущего», примера для взрослых. Довоенная детская литература рисовала образы отважных борцов с пережитками прошлого, а пионеры-мученики пополнили пантеон советских героев. В «Антирелигиозной азбуке» М. Черемных веселый малыш в военной форме и буденовке выступает проводником антирелигиозных лозунгов. Умирающая пионерка Валя из стихотворения Э. Багрицкого отвергает крест - предмет, не имеющий для нее сакрального смысла. Страха смерти Валя не испытывает, в отличие от матери, которую пугает безбожие дочери. Положение о том, что, «взяв это чувство на свое вооружение, религия обращает его в первую очередь против детей» [Быкова, с. 37], выполняло прежде всего алармистскую функцию, призывая общественность защитить будущее страны. Само государство стояло на страже «счастливого детства» и использовало широкий диапазон мер по ограждению детей от религиозного влияния: от демонизации верующих родителей в прессе до насильственного изъятия детей из верующих семей [Никольская, с. 191-197].

\footnotetext{
1 «Удивительна природа сего блаженного страха: вне его действия, очистительного, конечно, не откроется нам путь к совершенной любви Божией. Сам Он есть не только начало премудрости, но и любви. Он и потрясает душу нашу видением нас самих, как мы есть, и привязывает нас к Богу сильным желанием быть с Ним. Страх порождает изумление пред открывающимся нам Богом. Сознавать [себя] недостойным такого Бога - вот в чем ужас» [Софроний (Сахаров), с. 23].
} 
Создание виктимного детского образа происходило через несколько каналов: вербализированный (пресса, пособия о вреде религиозного воспитания, художественные произведения) и визуальный (карикатуры, художественный и игровой кинематограф).

Целевой аудиторией многочисленных пособий «Дети и религия» были родители, которым пытались донести мысль о том, что религиозный страх деформирует личность ребенка. С неодобрением подчеркивалось, что верующие родители часто использовали страх перед Богом и нечистой силой как педагогическое средство: «Для детей Бог - пугало, постоянный предмет устрашения» [Беляев, л. 8]. Заметим, что результаты социологических опросов начала 1960-х гг., проводившихся в разных регионах центральной части РСФСР, показали, что применение верующими родителями «педагогики страха» было не изобретением пропаганды, а укоренившейся за столетия традицией воспитания. В Ивановской области ученики начальных классов писали в анонимных сочинениях: «Бога боюсь, он наказывает тех, кто не верит в него»; «Верить не хочу, а боюсь»; «Про Бога рассказывали, что, как помрешь, будут мучить, и я Бога боюсь». «Судя по ответам учеников, верующие нередко запугивают детей», - сделал вывод автор статьи [Юдин, c. 59-60]. В материалах других соцопросов часто встречаются похожие идеи: в анонимных сочинениях учащихся школы рабочей молодежи из г. Кинешмы Ивановской обл. четверть респондентов упомянули использование взрослыми концепта возмездия за грехи для воспитания религиозности у детей [РГАСПИ. Ф. 606. Оп. 4. Д. 163].

В этот период на школу возлагалась особая задача атеистического воспитания, при необходимости - перевоспитания учащихся. Учителям предлагалось начинать работу с выявления «скрытой религиозности» детей через косвенные вопросы, связанные с темой урока [Дубовка]. Применение данной методики показало, что дети из нерелигиозных семей часто были хорошо знакомы с основами веры и церковными обрядами [Методика выявления]. В этих случаях религиозная социализация происходила через бабушек или пожилых соседок по дому, с которыми оставляли ребенка. Родители снисходительно относились к религиозному воспитанию, признавая нравственную силу религии и ее благотворное влияние на детей [Там же], а также то, что оно «делает детей добрее, счастливее, облегчает привитие им нужных моральных качеств» [Радина, 1961, с. 4]. Верующие в письмах в центральные СМИ ставили вопросы о моральном облике молодежи [ОР РНБ. Ф. 1152. Д. 2676], обращали внимание на ее «распущенность», объясняли отсутствие доброты и жестокость тем, что она «не воспитывается в законе Божьем», подчеркивали положительное воздействие религиозного воспитания [Там же. Д. 2620, 2487, 2667]. Таким родителям транслировали мысль о том, что незаметно для них их «ребенок может вырасти забитым, слабовольным, трусливым, с болезненной восприимчивостью и рядом других отрицательных качеств» [Беляев, л. 9]. Кроме того, эти качества и недостаток общения 
со сверстниками провоцировали значительные трудности в социализации и интеграции в атеистическое окружение уже на дошкольном уровне. Атеистические пособия содержали многочисленные примеры «дикости» верующих детей, к примеру, при поступлении в детский сад девочка, встав на колени, начала креститься перед портретом Крупской, приняв ее за икону [Беляев, л. 9].

Заметим, что безразличие родителей к религиозному влиянию старшего поколения воспринималось как равнодушие к судьбе ребенка. На рисунке Ю. Федорова «Мама смотрит сквозь пальцы» посещение подростком храма вместе с бабушкой приравнивалось к таким девиациям, как курение, издевательство над животными и обида слабых (ил. 6 на цв. вклейке). Благообразность хулигана, идущего в храм, усиливало положение о «раздвоенности, ханжестве, лицемерии» религиозных детей, о чем много писали в пособиях «Женщина и религия», целевой аудиторией которых были именно верующие матери [Притчина, с. 49]. В. Смолкин обнаружила в архиве выступление семиклассника на школьном собрании, который жаловался на противоречивые установки в воспитании в школе и семье: «Учителя говорят, кто пойдет в церковь, отметки снизят, а родители говорят, не пойдешь в церковь - из дому выгонят. Кого же нам слушаться?» [Смолкин, с. 179]. Также считалось, что религиозное воспитание влияло и на интеллектуальное развитие детей: «Религиозность подростков... находится в прямой зависимости от степени их общего развития... Основную массу верующих детей составляют учащиеся, отстающие в школе по многим предметам и не интересующиеся литературой. Ограниченность умственного кругозора учащихся благоприятствует возникновению и развитию у них религиозности» [Быкова, с. 34]. В то же время в статьях для педагогов о работе с верующими детьми подчеркивалось, что не все ученики соответствуют распространенным стереотипам. Например, «ученики средней школы г. Рыбинска Юрий А. (8-й класс) и его брат Николай (9-й класс) с дошкольного возраста воспитывались в дореволюционном духе. Они читали Священное Писание, регулярно посещали церковь, совершали религиозные обряды. Волевые, начитанные юноши учились на “4” и "5"» [Нетылько, с. 32].

Воспитание в атмосфере страха порождало отношения «карателя и жертвы», где возмездие приходило со стороны родителей. В атеистическом дискурсе роли христианских мучеников и их преследователей менялись местами [Панченко]. Верующие родители были представлены фанатиками, которых вера толкает на проявления крайней жестокости по отношению к детям [Беляев; Притчина; Dobson].

Композиционным центром рисунка «С Божьей помощью» выступает поникшая фигура маленького мальчика, которому после жестокого наказания велели встать в угол под икону Богородицы. Поза ребенка демонстрирует боль, стыд и покорность внешней силе, сюжет вызывает мысль о несопоставимой жестокости родителя и про- 
ступка, каким бы он ни был (ил. 7 на цв. вклейке). Ассоциативная связь между телесными наказаниями и религией как мировоззрением темного дореволюционного прошлого выстраивалась в рамках противопоставления методов условной дореволюционной и прогрессивной советской педагогики.

Атеистическая пропаганда всегда подчеркивала гендерный аспект женской религиозности, объясняя ее психологическими особенностями пола. Однако визуальная пропаганда выбирала в основном подростков и юношей для демонстрации виктимности. Ключевой особенностью юношеских образов стала антимаскулинность: их тела мягки и податливы, лишены мускулатуры советского маркера здорового, полноценного развития, поза выражает раболепие, несамостоятельность, покорность пожилым родственницам, которые, очевидно, принимают за них все решения в жизни, робкое, потерянное выражение лица не говорит о том, что ребенок живет счастливой, полной жизнью (рис. 1; ил. 8 на цв. вклейке).

Отсутствие маскулинности мы наблюдаем и у главных персонажей атеистических фильмов: оно проявляется в уклонении от службы в армии (этот сюжет часто встречался в атеистической прессе, особенно в материалах о разоблачении дезертиров в период Великой Отечественной войны [Осипов; Шамаро; Романов]), в робкой позе, тихом, вкрадчивом голосе. Поведение потенциального жениха главной героини фильма «Грешница», тайного адепта одной из протестантских церквей, противопоставляется жизнерадостности и честности колхозника Алексея - обаятельного шофера, мастера на все руки, баяниста. Жених вызывает у Ксении брезгливость: он симулировал болезнь для того, чтобы не служить в армии, печет пирожки, чтобы завоевать ее симпатию (то есть занимается исключительно женским делом), тих, робок, опрятен. Похожими качествами обладает главный герой известного фильма «Тучи над Борском» старшеклассник Савченко. Верующие юноши на экране практически лишены эмоций, основной круг их общения составляют пожилые верующие женщины, единственный досуг которых - хоровое исполнение псалмов. 
В средствах визуальной пропаганды детские образы часто сопровождает отрицательный образ пожилой женщины. В хрущевское время бабушка в силу занятости родителей становится человеком, с которым у ребенка устанавливается наиболее близкая эмоциональная связь [Ромашова]. Осознавая, что женщины старшего поколения являются основным источником сохранения и передачи религиознонравственной традиции, пропаганда демонизировала их влияние на внуков. В художественных фильмах («Конец света») и литературных произведениях («Чудотворная» В. Тендрякова, «Старшая сестра» Л. Воронковой) бабушки верят, но вера их страшная, жестокая, лишенная любви к людям.

Тема детской виктимности вызвала большой отклик среди взрослого населения СССР. В письмах в прессу выражалось негодование по поводу наиболее известных случаев абьюзивного отношения к детям. В 1960 г. члены бригады коммунистического труда московского завода «Станколит» написали коллективное письмо министру просвещения РСФСР Е. И. Афанасенко, которое было опубликовано на страницах журнала «Наука и религия» [Почему школа отступает без боя?]. Авторы письма выразили обеспокоенность тем, «как церковники затягивают в свои сети молодежь и детей. Мы читали об этом в “Комсомольской правде”, “Московском комсомольце”, “Вечерней Москве” и в других органах нашей печати в таких статьях, как “Хамелеон”, “Папа, мама и бидон святой воды”, “Отдали без боя”, "Уступили без боя" и т. п.». Наибольшее возмущение вызвал случай Жени Моисеева из Сызрани: его мама, молодая женщина, отправляла десятилетнего сына в Загорск, «чтобы купить там с помощью “Божьих старушек” бидон святой воды, лампадное масло, просвирки и занавес с распятьем. Женя Моисеев перешел в четвертый класс, Люда, его сестра, в шестой - и оба не пионеры» [Там же, с. 3]. Значительное расстояние более чем в 700 км мальчику предстояло преодолеть на поезде, делая пересадку в Москве. Рабочих возмущали не только безответственность матери и равнодушие отца-атеиста, но и пассивное отношение школы, которая должна была выступать «главной коллективной силой... призванной формировать здоровое атеистическое мировоззрение наших детей». Подобные письма часто появлялись в печати в эпоху оттепели и, по предположению части историков, были написаны журналистами [Никольская, с. 181]. Однако архив бывшего преподавателя Александро-Невской семинарии Александра Осипова содержит письма от частных лиц, авторы которых осуждают поведение верующих и выражают беспокойство за советских детей [ОР РНБ. Ф. 1152. Д. 2521, 2553].

Смещение Н. С. Хрущева и отход от агрессивных методов атеистической пропаганды позволили выйти в свет более объективным работам по психологии детской религиозности. Развитие психологии религии в СССР с 1960-х гг. и изучение эмоций как отдельной предметной области позволили несколько отойти от примитивных 
установок о «страхе Божьем» и обратиться к более глубокому пониманию внутреннего мира верующих. Исследования в области психологии религии теперь строились на эмпирической базе социологических опросов верующих и наблюдений за ними. Со временем появились публикации, в которых доказательно проводилась мысль о том, что эмоциональный мир верующих нельзя сводить исключительно к воздействию страха.

Эволюцию в освещении этой проблемы можно проследить на примере публикаций кандидата педагогических наук К. Д. Радиной, ранние работы которой уже цитировались в этой статье. В 1965 г. в журнале «Советская педагогика» вышла статья Ксении Давыдовны о психологических особенностях религиозных переживаний в детском возрасте, стиль которой сильно отличается от ее работ более раннего периода: она лишена обличительного тона, пропагандистского настроя и стереотипов. Объектом наблюдения в работе стали подростки 12-15 лет нескольких ленинградских школ, анализу в ходе исследования подверглись словесные высказывания и поведенческие реакции учащихся. Эмоциональный диапазон верующего ребенка расширился: теперь он мог испытывать чувства «умиления, умиротворения, радости, вызывающие особое молитвенное настроение... восхищение, общий эмоциональный подъем, приводящий к экстазу» [Радина, 1965, с. 54].

Автор подчеркнула, что «вера в Бога только на страхе не может держаться. Страх отпугивает, отталкивает ребенка. Подрастая, многие дети преодолевают это чувство, но не всегда освобождаются при этом от религиозной веры. В ее основе лежат теперь иные чувства, и мы пришли к выводу, что одним из них является своеобразное “чувство защищенности”, остро переживаемая надежда на “помощь Божию”, которую всячески поддерживают и укрепляют верующие взрослые». Однако полностью выйти за рамки принятой парадигмы автор не смогла: «Ведь не случайно для большинства религиозных детей характерны слабость воли, нерешительность, неуверенность. Неуверенные в себе, они надеются на “помощь Божию”, охотно к ней прибегают в трудные минуты жизни. Всякого рода случайные совпадения фиксируются в их сознании, усиливают чувство защищенности, поддерживают религиозные предрассудки» [Там же, с. 55].

Несмотря на то, что психология религии в изучении эмоционального портрета верующего человека отошла от стереотипных положений, пропаганда продолжала использовать привычный образ ребенка-жертвы в силу его привычности и эффективности для атеистической работы. В брежневский период в СССР продолжали издаваться массовыми тиражами пособия «Дети и религия», которые повторяли и развивали основные положения о религиозном страхе и его влиянии на детей [Огрызко]. Архетипичный образ ребенкажертвы оказался очень удобным инструментом для борьбы с религиозностью: уходя корнями в образы традиционной русской детской 
святости, детей-мучеников [Романова], он вторил визуальному дискурсу времен Великой Отечественной, взывающему к защите детей от внешней угрозы. Стереотип о прививаемом «страхе Божьем» оказался устойчивым ввиду повсеместного «бытового» использования «педагогики страха» как метода воспитания, что делало его частью личного опыта населения советского пространства.

\section{Список литературы}

Беляев К. И. Религия и дети : Материал в помощь лектору. М. : Моск. гор. отд. О-ва по распространению полит. и науч. знаний РСФСР, 1959. 25 л.

Быкова Г. Г. Причины возникновения и проявления религиозности у подростков // Советская педагогика. 1963. № 8. С. 31-40.

Дубовка А. Кто из детей верит в бога? // Наука и религия. 1963. № 2. С. 74-77.

Иоанн Лествичник, преп. Лествица, или Скрижали духовные. Слово 21. О малодушной боязливости, или страховании // Азбука веры : [сайт]. URL: https://azbyka. ru/otechnik/Ioann_Lestvichnik/lestvitsa-ili-skrizhali-dukhovnye/26 (дата обращения: 05.05.2020).

История религий во Владимирском крае (советский период) / отв. ред. Е. И. Аринин. Владимир : Шерлок-пресс, 2018. 200 с.

Костюков И. Плутни лукавого // Крокодил. 1962. № 3. С. 8.

Костюков И. Божьи угодники // Крокодил. 1964. № 24. С. 4.

Методика выявления отношения детей к религии в 1-4 классах : В помощь учителю. М. : Моск. гор. организация о-ва «Знание» РСФСР : Дом науч. атеизма, 1967. 16 с.

Нетылько А. М. Об индивидуальном подходе в атеистическом воспитании учащихся // Советская педагогика. 1963. № 6. С. 31-36.

Никольская T. К. Русский протестантизм и государственная власть в 1905-1991 годах. СПб. : Изд-во Европ. ун-та в Санкт-Петербурге, 2009. 353 с.

Никольский А. Как комплектуют команды // Крокодил. 1964. № 2. С. 8-9.

О недостатках научно-атеистической пропаганды : записка Отдела пропаганды и агитации ЦК КПСС по союзным республикам от 12.09.1958 // Российское объединение исследователей религии : [сайт]. URL: https://rusoir.ru/03print/03print02/03print-02-239/ (дата обращения: 17.01.2021).

Огрызко И. И. Дети и религия. 2-е изд., испр. и доп. Л. : Лениздат, 1970. 151 с.

Opeл E. В. Советская психология религии в 60-70-х гг. XX века: заметки на полях // Вестн. ПСТГУ. Сер. 1: Богословие. Философия. Религиоведение. 2018. № 75. C. 102-110. DOI 10.15382/sturI201875.102-110.

Осипов И. Второе лицо «учителя» Мокрова // Учительская газета. 1959. № 137. C. 2 .

ОР РНБ. Ф. 1152. Д. 2487, 2494, 2521, 2553, 2620, 2667, 2676.

Панченко A. A. «Религиозные инфекции» и «духовные калеки»: тема детства в советской атеистической пропаганде 1960-х гг. // «Убить Чарскую...»: парадоксы советской литературы для детей, 1920-е - 1930-е гг. / сост. и ред. М. Р. Балина, В. Ю. Вьюгин. СПб. : Алетейя, 2013. С. 310-329.

Почему школа отступает без боя? // Наука и религия. 1960. № 9. С. 3-5.

Притчина Е. А. Женщина и религия. М. : Сов. Россия, 1960. 55 с.

Радина К. Д. Атеистическое воспитание детей в семье. Л. : Всесоюз. о-во по распространению полит. и науч. знаний, 1955. 32 с.

Радина К. Д. Какой вред приносит религия детям. Л. : О-во по распространению полит. и науч. знаний РСФСР, 1961. 47 с.

Радина К. Д. Особенности эмоциональных состояний подростков, подверженных религиозному влиянию // Советская педагогика. 1965. № 8. С. 55.

Романов А. Духовный скит предателя // Наука и религия. 1963. № 2. С. 24-27. 
Иллюстрации к статье:

Галина Егорова. Страх и детская виктимность в атеистическом дискурсе хрущевского периода

Illustration for the article:

Galina Egorova. Fear and Childhood Victimisation in Atheistic Discourse during the Khrushchev Era

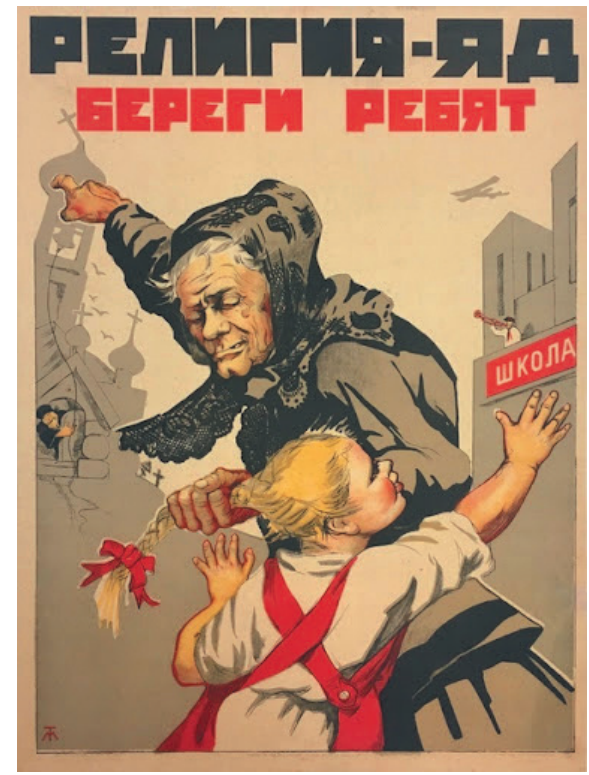

5. «Религия - яд, береги ребят!» Плакат Н. Терпсихорова. 1930

“Religion is a poison! Protect your children!" Poster by N. Terpsykhorov. 1930

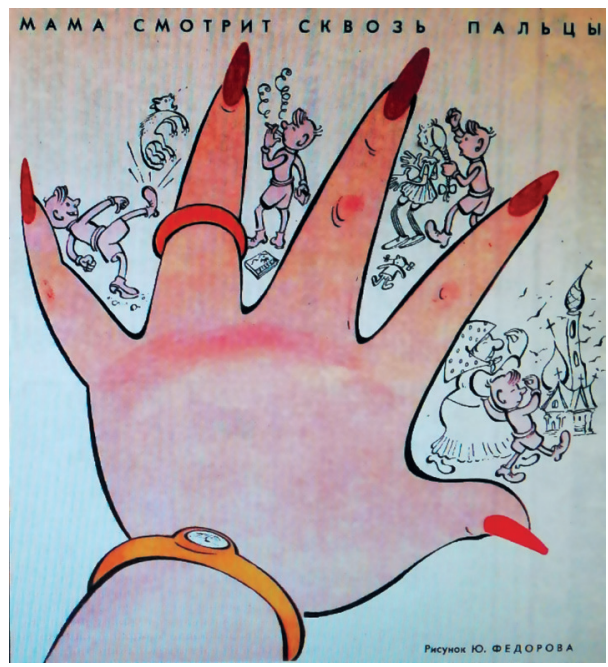

6. «Мама смотрит сквозь пальцы». Рис. Ю. Федорова. Крокодил. 1964. № 5

“Mother Turns a Blind Eye." Ill. by Yu. Fedorov. Krokodil. 1964. No. 5 


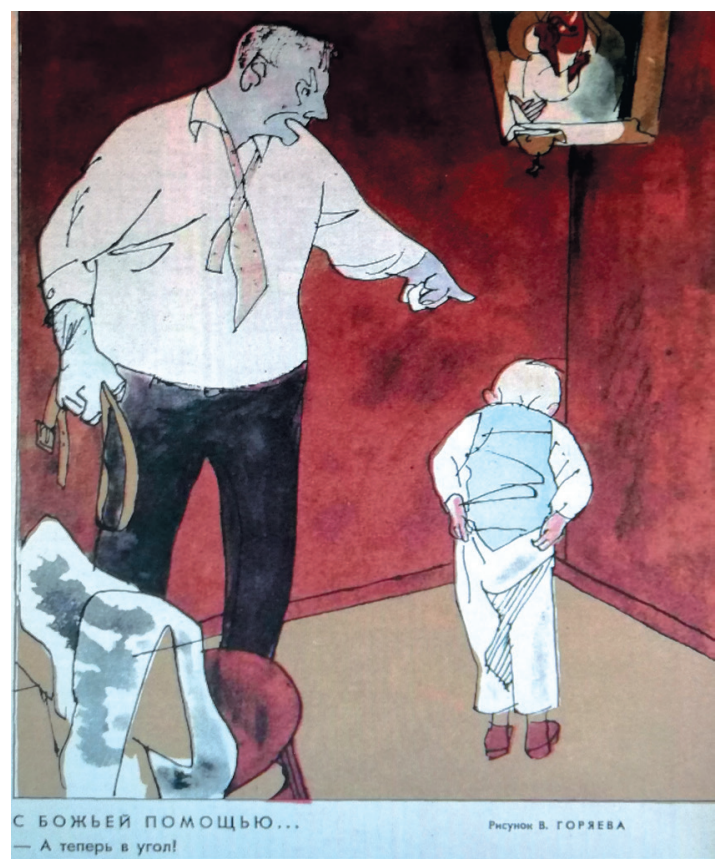

7. «С Божьей помощью». Рис. В. Горяева. Крокодил. 1964. № 8 "With God's Help." Ill. by V. Goryaev. Krokodil. 1964. No. 8

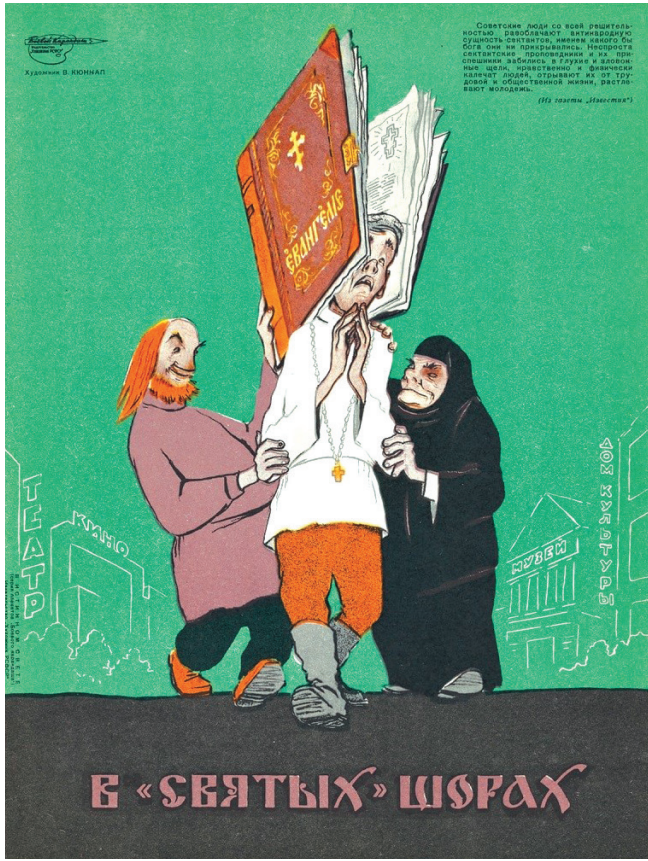

8. «B “святых” шорах». Плакат В. Кюннапа. 1962 "In the 'Holy' Blinders." Poster by V. Künnap. 1962 
Романова А. А. Почитание святых детей как феномен русской святости в XVII веке // Научный диалог. 2016. № 9 (57). С. 205-216.

Ромашова M. «Дефицитная» бабушка: советский дискурс старости и сценарии старения // Новое лит. обозрение. 2015. № 3. С. 55-65.

РГАСПИ. Ф. 606. Оп. 4. Д. 163.

Семенов $M$. Богомолье во Владимире : репортаж в пасхальную ночь // Крокодил. 1963. № 12. C. $12-13$.

Смолкин В. Свято место пусто не бывает: история советского атеизма. М. : Новое лит. обозрение, 2021. 552 с.

Софроний (Сахаров), архим. Видеть Бога как Он есть. Изд. 3-е, испр. Эссекс : Свято-Иоанно-Предтеченский монастырь, 2006. 400 с.

Сувениры суеверий // Наука и религия. 1961. № 6. С. 61.

Федоров A. B. Опыт герменевтического анализа советских аудиовизуальных медиатекстов антирелигиозной тематики на занятиях в студенческой аудитории // Инновации в образовании. 2013. № 7. С. 78-94.

Шамаро А. «Брат во Христе» из Людиново // Наука и религия. 1961 . № 9. С. 79-81.

Шатров Е. Бабка Аксинья спешит в музей // Крокодил. 1960. № 13. С. 8.

Школа не может быть нейтральной // Наука и религия. 1961 № 9. С. 13-14.

Юдин А. Индивидуальный подход в атеистической работе // Коммунист. 1965. № 15. C. 59-60.

Dobson M. Child Sacrifice in the Soviet Press: Sensationalism and the "Sectarian" in the Post-Stalin Era // Russian Rev. 2014. № 2 (73). P. 237-259. DOI 10.1111/russ.10728.

Fitzpatrick Sh. Happiness and Toska : An Essay in the History of Emotions in Prewar Soviet Russia // Australian J. of Politics and History. Vol. 50. 2004. № 3. P. 357-371. DOI 10.1111/j.1467-8497.2004.00339.x.

\section{References}

Arinin, E. I. (Ed.). (2018). Istoriya religii vo Vladimirskom krae (sovetskii period) [A History of Religions in Vladimir Region (the Soviet Period)]. Vladimir, Sherlok-press. 200 p.

Belyaev, K. I. (1959). Religiya i deti: Material v pomoshch' lektoru [Religion and Children: A Lecturer's Handbook]. Moscow, Moskovskoe gorodskoe otdelenie Obshchestva po rasprostraneniyu politicheskikh i nauchnykh znanii RSFSR. 251.

Bykova, G. G. (1963). Prichiny vozniknoveniya i proyavleniya religioznosti u podrostkov [The Causes of the Emergence and Manifestation of Religiosity in Adolescents]. In Sovetskaya pedagogika. No. 8. pp. 31-40.

Dobson, M. (2014). Child Sacrifice in the Soviet Press: Sensationalism and the "Sectarian" in the Post-Stalin Era. In Russian Rev. No. 2 (73), pp. 237-259. DOI 10.1111/russ. 10728.

Dubovka, A. (1963). Kto iz detej verit v boga? [Which Children Believe in God?]. In Nauka i religiya. No. 2, pp. 74-77.

Fedorov, A. V. (2013). Opyt germenevticheskogo analiza sovetskikh audiovizual'nykh mediatekstov antireligioznoi tematiki na zanyatiyakh $\mathrm{v}$ studencheskoi auditoria [An Attempt at an Hermeneutic Analysis of Soviet Audiovisual Media Texts on AntiReligious Themes in Classes with Students]. In Innovatsii v obrazovanii. No. 7, pp. 78-94.

Fitzpatrick, Sh. (2004). Happiness and Toska: An Essay in the History of Emotions in Pre-war Soviet Russia. In Australian J. of Politics and History. Vol. 50. No. 3, pp. 357-371. DOI 10.1111/j.1467-8497.2004.00339.x.

Ioann Lestvichnik, revd. (N. d.). Lestvitsa, ili Skrizhali dukhovnye. Slovo 21. O malodushnoi boyazlivosti, ili strakhovanii [The Venerable Ladder, or Spiritual Tablets. Word 21. About Cowardly Fearfulness, or Insurance]. In Azbuka very [website]. URL: https://azbyka.ru/otechnik/Ioann_Lestvichnik/lestvitsa-ili-skrizhali-dukhovnye/26 (accessed: 05.05.2020)

Kostyukov, I. (1962). Plutni lukavogo [Tricks of the Deceiver]. In Krokodil. No. 3, p. 8.

Kostyukov, I. (1964). Bozh'i ugodniki [God's Saints]. In Krokodil. No. 24, p. 4. 
Metodika vyyavleniya otnosheniya detei $k$ religii v 1-4 klassakh. V pomoshch'uchitelyu [Methods of Identifying Children's Attitudes towards Religion in Grades 1-4. A Teacher's Handbook]. (1967). Moscow, Moskovskaya gorodskaya organizatsiya obshchestva "Znanie" RSFSR, Dom nauchnogo ateizma. 16 p.

Netyl'ko, A. M. (1963). Ob individual'nom podkhode $\mathrm{v}$ ateisticheskom vospitanii uchashchikhsya [On the Individual Approach in the Atheistic Education of Students]. In Sovetskaya pedagogika. No. 6, pp. 31-36.

Nikol'skaya, T. K. (2009). Russkii protestantizm i gosudarstvennaya vlast'v 1905-1991 godakh [Russian Protestantism and the State in 1905-1991]. St Petersburg, Izdatel'stvo Evropeiskogo universiteta v Sankt-Peterburge. 353 p.

Nikol'skii, A. (1964). Kak komplektuyut komandy [How Teams are Completed]. In Krokodil. No. 2, pp. 8-9.

O nedostatkakh nauchno-ateisticheskoi propagandy. Zapiska Otdela propagandy i agitatsii TsK KPSS po soyuznym respublikam ot 12.09.1958 [On the Shortcomings of Scientific and Atheistic Propaganda. Note of the Department of Propaganda and Agitation of the Central Committee of the CPSU for the Union Republics from 09.12.1958]. (1958). In Rossiiskoe ob"edinenie issledovatelei religii. URL: https://rusoir.ru/03print/03print02/03print-02-239/ (accessed: 17.01.2021).

Ogryzko, I. I. (1970). Deti i religiya [Children and Religion]. $2^{\text {nd }}$ Ed., corr. and add. Leningrad, Lenizdat. $151 \mathrm{p}$.

$O R R N B$ [Department of Manuscripts of the National Library of Russia]. Stock 1152. Dos. 2487, 2494, 2521, 2553, 2620, 2667, 2676.

Orel, E. V. (2018). Sovetskaya psikhologiya religii v 60-70-kh gg. XX veka: zametki na polyakh [The Soviet Psychology of Religion in the 1960s-1970s: Marginalia]. In Vestnik Pravoslavnogo Svyato-Tikhonovskogo gumanitarnogo universiteta. Seriya 1: Bogoslovie. Filosofiya. Religiovedenie. No. 75, pp. 102-110. DOI 10.15382/sturI201875.102-110.

Osipov, I. (1959). Vtoroe litso "uchitelya" Mokrova [The Second Face of "Teacher" Mokrov]. In Uchitel'skaya gazeta. No. 137, p. 2.

Panchenko, A. A. (2013). "Religioznye infektsii" i "dukhovnye kaleki": tema detstva v sovetskoi ateisticheskoi propagande 1960-kh gg. ["Religious Infections" and "Spiritual Cripples": The Topic of Childhood in Soviet Atheistic Propaganda of the 1960s]. In Balina, M. R., V'yugin, V. Yu. (Eds.). “Ubit' Charskuyu...”: paradoksy sovetskoi literatury dlya detei, 1920-e-1930-e gg. St Petersburg, Aleteiya, pp. 310-329.

Pochemu shkola otstupaet bez boya? [Why Does the School Retreat without a Fight?]. (1960). In Nauka i religiya. No. 9, pp. 3-5.

Pritchina, E. A. (1960). Zhenshchina i religiya [Woman and Religion]. Moscow, Sovetskaya Rossiya. 55 p.

Radina, K. D. (1955). Ateisticheskoe vospitanie detei v sem'e [The Atheistic Education of Children in the Family]. Leningrad, Vsesoyuznoe obshchestvo po rasprostraneniyu politicheskikh i nauchnykh znanii. $32 \mathrm{p}$.

Radina, K. D. (1961). Kakoi vred prinosit religiya detyam [What Harm Religion Does to Children]. Leningrad, Obshchestvo po rasprostraneniyu politicheskikh i nauchnykh znanii RSFSR. 47 p.

Radina, K. D. (1965). Osobennosti emotsional'nykh sostoyanii podrostkov, podverzhennykh religioznomu vliyaniyu [Features of the Emotional States of Adolescents Subjected to Religious Influence]. In Sovetskaya pedagogika. No. 8, p. 55.

RGASPI [Russian State Archive of Socio-Political History]. Stock 606. List 4. Dos. 163.

Romanov, A. (1963). Dukhovnyi skit predatelya [The Spiritual Skete of the Traitor]. In Nauka i religiya. No. 2, pp. 24-27.

Romanova, A. A. (2016). Pochitanie svyatykh detei kak fenomen russkoi svyatosti v XVII veke [The Veneration of Holy Children as a Phenomenon of Russian Holiness in the $17^{\text {th }}$ Century]. In Nauchnyi dialog. No. 9 (57), pp. 205-216.

Romashova, M. (2015). "Defitsitnaya" babushka: sovetskii diskurs starosti i stsenarii stareniya ["Deficit" Grandmother: The Soviet Discourse of Old Age and Scenarios of Aging]. In Novoe literaturnoe obozrenie. No. 3, pp. 55-65. 
Semenov, M. (1963). Bogomol'e vo Vladimire. Reportazh v paskhal'nuyu noch' [A Prayer in Vladimir: A Report on Easter Night]. In Krokodil. No. 12, pp. 12-13.

Shamaro, A. (1961). "Brat vo Khriste" iz Lyudinovo [A "Brother in Christ" from Lyudinovo]. In Nauka i religiya. No. 9, pp. 79-81.

Shatrov, E. (1960). Babka Aksin'ya speshit v muzei [Grandma Aksinya Hurries to the Museum]. In Krokodil. No. 13, p. 8.

Shkola ne mozhet byt' neitral'noi [School Cannot Be Neutral] (1961). In Nauka i religiya. No. 9, pp. 13-14.

Smolkin V. (2021). Svyato mesto pusto ne byvaet: istoriya sovetskogo ateizma [A Holy Place is Never Empty: The History of Soviet Atheism]. Moscow, Novoe literaturnoe obozrenie. $552 \mathrm{p}$.

Sofronii, (Sakharov), archim. (2006). Videt'Boga kak On est' [Perceive God as He Is]. $3^{\text {rd }}$ Ed., corr. Essex, Svyato-Ioanno-Predtechenskii monastyr'. 400 p.

Suveniry sueverii [Souvenirs of Superstition]. (1961). In Nauka i religiya. No. 6, p. 61.

Yudin, A. (1965). Individual'nyi podkhod $\mathrm{v}$ ateisticheskoi rabote [The Individual Approach in Atheistic Work]. In Kommunist. No. 15, pp. 59-60.

The article was submitted on 14.10 .2020 